\title{
Fostering 21st Century Skills of the Students of Engineering and Technology
}

\author{
S. Mekala ${ }^{1}$, C. Harishree ${ }^{2}$, Geetha $\mathbf{R}^{3}$ \\ ${ }^{123}$ Department of Humanities and Social Sciences, National Institute of Technology, Tiruchirappalli -620015. \\ 1mekala@nitt.edu \\ ${ }^{2}$ hshree20@gmail.com \\ 'seethenglish@gmail.com
}

\begin{abstract}
Employment opportunities are scramming from the reach of Indian engineering graduates due to their inadequate skills set. This evinces the skills gap prevailing between the workplace preparedness of the students of engineering and the exigencies of global workforce. 21 st Century Skills are the competencies required from the students of present era to succeed in their life and career, in the absence of which the students encounter major employment deficit. Although, studies have been conducted on the need for 21 st Century skills and on training teachers to instigate students' skills set, the inevitable focus on students' perception towards their need for career prospects has been left unexplored. Hence, the paper prospects the preparedness and potential of the students of engineering with respect to Learning and Innovation Skills and Life and Career Skills of 21st Century Skills. An online survey with self-rating questionnaire has been administered using random sampling technique among 111 final year students of Mookambigai College of Engineering and Dhanalakshmi Srinivasan Engineering College, Tamil Nadu, between December 2018 and January 2019. Descriptive analysis, and parametric tests have been computed to investigate the data using SPSS.
\end{abstract}

\section{Harishree}

Department of Humanities and Social Sciences,

National Institute of Technology, Tiruchirappalli -620015.

hshree20@gmail.com
The findings have indicated the dearth of students' skills set in employing 21st Century skills set. The results imply the desideratum of enhancing the students' skills set that the study eventually recommends the integration of 21 st Century skills set in English classroom of engineering and technology to meet the demands of the workplace.

Keywords: Workplace Preparedness; 21st Century Skills; Students of Engineering and Technology; Engineering Curriculum.

\section{Introduction}

21 st Century Skills refer to the aptitudes and attitudes demanded of the employees to be widely demonstrated in the global workplace. In this regard, higher education institutions bear responsibility to ensure the capabilities of the employees in fulfilling the workplace requirements. Partnership for $21 \mathrm{st}$ Century skills (P21) has developed 21st Century skills framework to equip the students for future workplace. This framework has been adopted in many countries across the globe and been successful in improving the students' skills set.

The P21 framework classifies 21st Century skills set into Learning and Innovation skills, Information, Media and Technology skills, and Life and Career skills. Learning and Innovation skills encompass Creativity and Innovation, Critical Thinking and Problem Solving, Communication and Collaboration. Life and Career skills comprise Flexibility and 
Adaptability, Initiative and Self-Direction, Productivity and Accountability, Social and CrossCultural skills, and Leadership and Responsibility skills. These skills establish a paramount role in the discharge of workplace duties and in the selfimprovement of the employees. Accordingly, the paper focuses on the need for implementing these skills set in the classroom to prepare the students of engineering and technology for global competition in the workplace, counting the prevalence of skills gap between the workplace preparedness of the students of engineering and the industrial requirements.

The survey reports by organizations like Aspiring minds (2016), PeopleStrong et al. (2018), and National Skill Development Corporation (NSDC) (2007) have identified that India has a large number of unemployed engineering graduates due to the lack of requisite skills set. The lacuna in the skills set among young students is the critical issue to be addressed promptly. In the globalized era, the workplace environment demands the students to be prepared with requisite skills set, besides the content knowledge. The students of engineering and technology should be able to navigate their complex workplace situation towards the information age and they need to develop adequate " 21 st Century Skills" to succeed in the world of work. Educational Leadership has propounded, "growing number of business leaders, politicians and educators are united around the idea that students need ' 21 st Century Skills' to be successful today" (as cited in Oliver, 2016). In this line, it is essential to identify the students' skills set and assert the skills gap between industrial requirement and students' preparation. This paper explores the necessity to improve the 21 st Century skills of the students of engineering and technology and the effectiveness of English teachers in developing these skills set among the students of engineering. The paper confines to Learning and Innovation skills (refer Fig.1) and Life and Career skills (refer Fig.2) as they accommodate the elemental expertise statutory to the organizational and personnel success.

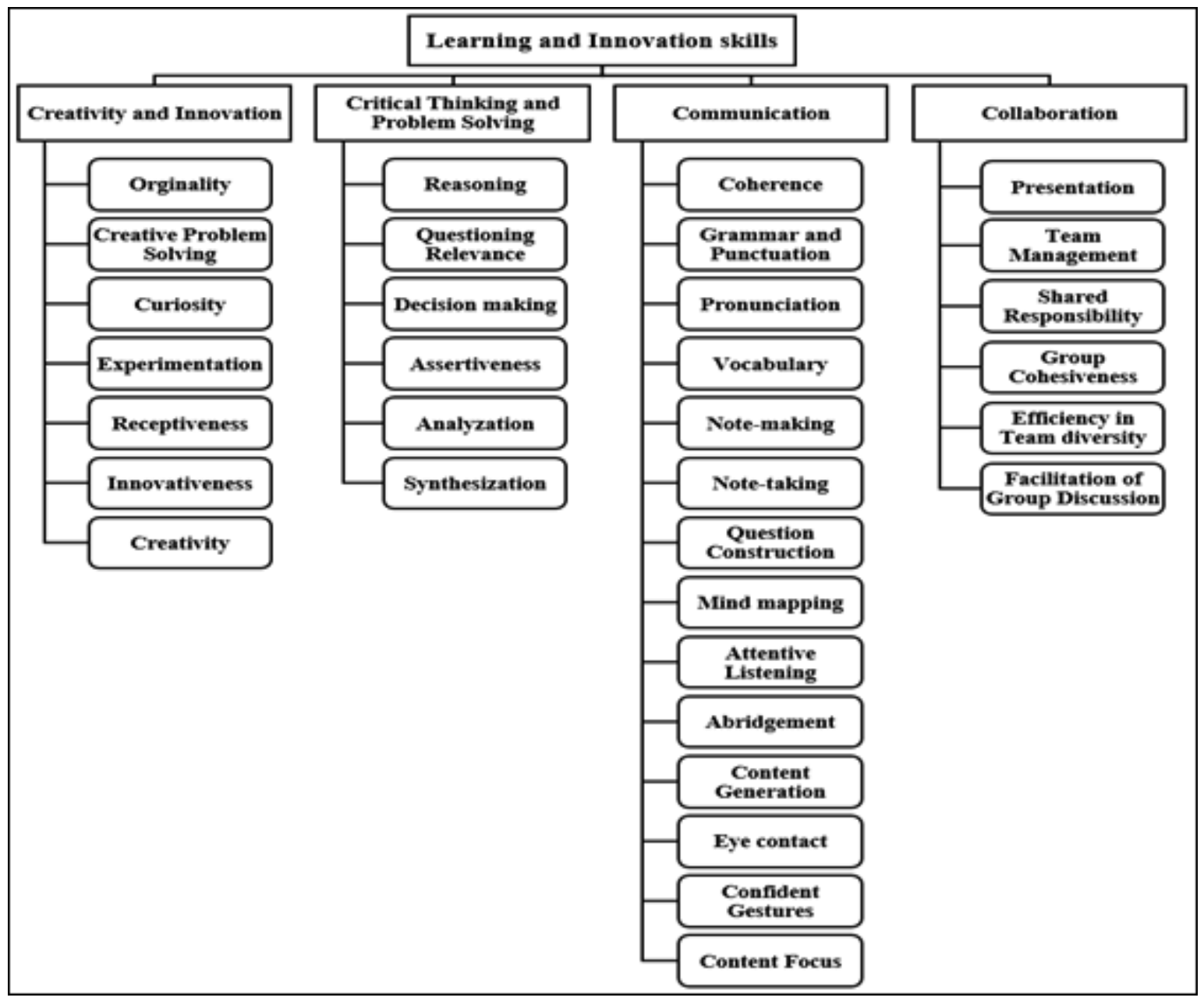

Fig.1 : Tenets of Learning and Innovation skills 


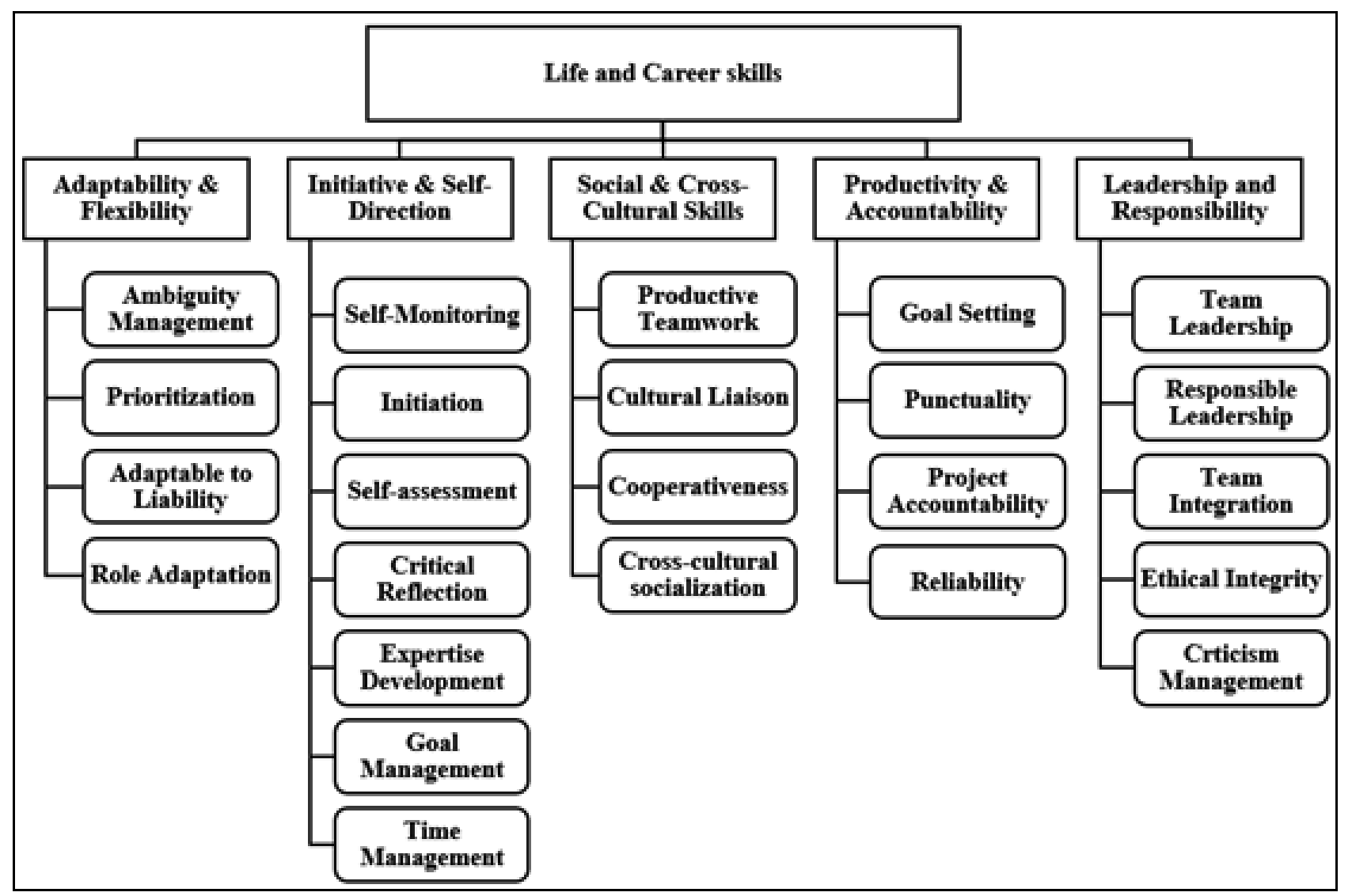

Fig. 2 : Tenets of Life and Career skills

\section{Review Of Literature}

The Partnership for 21st Century Skills (P21) has developed a framework with the help of thirty-five organizations, members from educational departments and research organizations to improve the readiness of new entrants in the U.S. Workforce (as cited in Casner-Lotto \& Barrington, 2006). Suto (2013) has stated that the 21 st Century skills has become "international, multicultural and interconnected new skills" which are essential for the career prospects. Dede (2009) has compared different frameworks and has found that P21 framework is the most consistent framework in preparing the students for their future workplace. Trilling and Fadel (2009) have stated that the framework developed by P21 guide the evolution of the education landscape.

McLachlan (2012) has studied how programs and practices of schools are oriented towards 21 st Century skills. Likewise, Sloka et al. (2015) have received opinions of the employers from the regions of Latvia on their need and expectations from their employees and have found that the skills in the P21 framework holds major part in the employers' expectations on the new entrants. Soltis and Hastings (2017) have opined "It is imperative to better understand the areas of education and training required for the workforce" (p.6). Accordingly, the authors have conducted a survey in Roanoke regional employers by Virginia Western Community College addressing the need for soft skills, and have identified the workplace needs of Virginia.

Bhola and Dhanawade (2013) have explored that 64 percent of the employers are not fully satisfied with the skills set possessed by their workforce and there is a need for upgrading the skills set of the employees. Ramanan, Kumar and Ramanakumar (2015) have studied the influential factors developing the employability of the Mechanical Engineering graduates and have discussed the remedial measures at the institutional level to reduce the soft skills gap between the industry expectations and students' preparedness towards workforce. Unni (2016) has identified that "Large section of labour possesses outdated skills" (p. 1). Robbins (2017) has focused on the attainment of skills and its importance in the future workplace. Casner-Lotto and Barrington (2006) have reported the views of employers on the responsibility 
of colleges and universities in preparing the students to enter the workforce. Morell (2010) has analyzed the challenges in the engineering education to prepare the students for the 21 st Century industries and has questioned the reason for the retention and recruitment issues among the students of engineering in spite of the developments in outcome based educational curriculum.

Oliver (2016) has explored the constituents of 21 st Century skills and has suggested tactics to incorporate 21 st Century skills into the 'content-based' instructional programs. Meanwhile, Sural (2017) has proposed to integrate 21 st Century skills in the educational curriculum for effective teaching. Further, Chu et al. (2017) have outlined the development of 21st Century skills in Hong Kong, Switzerland, and USA and have recommended inquiry-based pedagogical approach to initiate $21 \mathrm{st}$ Century skills education. Samavedham and Ragupathi (2012) have explored the students' knowledge and skills concerning the 21st Century Skills and have proposed different aspects of curriculum design, classroom practices and assessment methods that can be implemented in the engineering education. A case study by Egnor (2013) has offered methods to facilitate the implementation of 21st Century skills in the elementary schools of Pennsylvania.

These studies have highlighted the need for enhancing the students' 21 st Century skills to meet the challenges of their future workplace. The need to improve the skills set is evident through the studies on the prevailing skills gap in the engineering sectors of India. But there is no study conducted on identifying the level of skills set of the students of engineering and technology in India. Hence, this paper explicates the potentiality of students of engineering and technology with specific reference to Learning and Innovation skills and Life and Career skills. Accordingly, the paper analyses the hypothesis on the need for improvement in students' Learning and Innovation skills and Life and Career skills with respect to the following research questions.

1. What is the perception of the students of engineering towards the workforce readiness with respect to Learning and Innovation skills and Life and Career skills?

2. Does Gender have an impact on the acquisition of 21st Century Skills among the students of engineering?
3. Do the students' medium of instruction at school influence their 21 st Century skills?

\section{Methodology}

A quantitative survey has been conducted to identify the preparedness of students of engineering and technology to meet the workplace requirements with respect to 21 st Century skills set. The online survey has been administered through google form among the students of engineering across disciplines at the time of recruitment between December 2018 and January 2019.

\section{A. Instrument}

Questionnaire, the research tool of the study has been framed based on the constructs of Learning and Innovation and Life and Career skills of P21 framework. Negative questioning technique is a reliable technique to avoid the usual types of bias and elicit participation by providing transparent privacy guarantees (Esponda and Guerrero, 2009). Hence, the questions related to 21st Century skills discussed in this paper have been negated to avoid the hesitation of the students in honestly revealing the actual knowledge of the skills they possess. The amount of information disclosed while answering a negative questionnaire is less than or equal to what is relinquished during the direct response version. Esponda and Guerrero (2009) have formalized this notion by quantifying the information surrendered to an observer. Hence, the questionnaire used in this survey includes negative questions that have increased the accuracy of the survey in disclosing the students' preparedness on 21st Century skills set. The Questionnaire is divided into two parts. Part A carries the demographic details of the students. Part B of the questionnaire consists of the tenets of the nine skills selected for the study and students have been asked to rate their ability with respect to these skills in a fivepoint Likert scale: 1 - Always and 5 - Never. The participants have spent on an average of around 15-20 minutes to complete the Questionnaire.

\section{B. Participants}

The random sampling technique has been used to select 111 respondents (R) (44 females and 67 males) of the final year students of engineering and technology. The chosen samples are in the age group of either 20 or 21 belonging to Mookambigai College of Engineering, Pudukottai and Dhanalakshmi Srinivasan Engineering College, Perambalur, Tamil 
Nadu. These students are from eight branches namely Civil Engineering (R-28), Electronics and Communication Engineering (R-20), Computer Science Engineering (R-13), Mechanical Engineering (R-17), Bio-Medical Engineering (R-14), Information Technology (R-2), Electrical and Electronics Engineering (R-12), Aeronautical Engineering (R-5).

\section{Data Analysis}

The data obtained through the online questionnaires have been analyzed using SPSS software to identify the students' skill level and their perception towards workforce readiness. The data have been subjected to descriptive analysis and parametric tests (Correlation analysis and Independent Samples T-Test).

1) Validity of the Questionnaire: Pearson's Correlation analysis has been computed to analyze the validity of the questionnaire. Table 1 indicates the significant value and the total score (rxy). The $\mathrm{r}$ table product moment of the questionnaire is 0.244 . The significant value being less than 0.05 and the rxy value greater than 0.244 in Table 1 exhibit that the items in the questionnaire are valid.

Table 1: Correlation Analysis

\begin{tabular}{|c|c|c|c|c|c|c|c|c|c|c|}
\hline & V1 & V2 & V3 & V4 & V5 & V6 & V7 & V8 & V9 & V10 \\
\hline \multicolumn{11}{|l|}{ V1 } \\
\hline & & & & & & & & & & \\
\hline \multirow[t]{2}{*}{$\mathrm{V} 2$} & $0.56^{* *}$ & & & & & & & & & \\
\hline & \begin{tabular}{|l|}
0.00 \\
\end{tabular} & & & & & & & & & \\
\hline \multirow[t]{2}{*}{ V3 } & $0.35^{* *}$ & $0.36^{* *}$ & & & & & & & & \\
\hline & \begin{tabular}{|l|}
0.00 \\
\end{tabular} & 0.00 & & & & & & & & \\
\hline \multirow[t]{2}{*}{$\mathrm{V4}$} & $0.56^{* * *}$ & $0.54^{* * *}$ & $0.43^{* *}$ & & & & & & & \\
\hline & \begin{tabular}{|l|}
0.00 \\
\end{tabular} & 0.00 & 0.00 & & & & & & & \\
\hline \multirow[t]{2}{*}{ V5 } & $0.35^{* *}$ & $0.40^{* *}$ & $0.76^{* *}$ & $0.49^{* *}$ & & & & & & \\
\hline & 0.00 & 0.00 & 0.00 & 0.00 & & & & & & \\
\hline \multirow[t]{2}{*}{ V6 } & \begin{tabular}{|l}
$0.31^{* *}$ \\
\end{tabular} & $0.33^{* *}$ & $0.72^{* *}$ & $0.37^{* *}$ & $0.86^{* * 2}$ & & & & & \\
\hline & 0.00 & 0.00 & 0.00 & 0.00 & 0.00 & & & & & \\
\hline \multirow[t]{2}{*}{ V7 } & $0.34^{* *}$ & $0.36^{* *}$ & $0.72^{* *}$ & $0.42^{* *}$ & $0.80^{* * 2}$ & $0.88^{* *}$ & & & & \\
\hline & 0.00 & 0.00 & 0.00 & 0.00 & 0.00 & 0.00 & & & & \\
\hline \multirow[t]{2}{*}{ V8 } & $0.32^{* *}$ & $0.41^{* *}$ & $0.78^{* *}$ & $0.46^{* *}$ & $0.90^{* * *}$ & $0.90^{* *}$ & $0.85^{* *}$ & & & \\
\hline & \begin{tabular}{|l|}
0.00 \\
\end{tabular} & 0.00 & 0.00 & 0.00 & 0.00 & 0.00 & 0.00 & & & \\
\hline \multirow[t]{2}{*}{ V9 } & \begin{tabular}{|l}
$0.22^{*}$ \\
\end{tabular} & $0.33^{* * *}$ & $0.67^{* *}$ & $0.36^{\text {** }}$ & $0.71^{* * *}$ & $0.75^{* *}$ & $0.72^{* *}$ & $0.77^{* 2}$ & & \\
\hline & \begin{tabular}{|l|}
0.02 \\
\end{tabular} & 0.00 & 0.00 & 0.00 & 0.00 & 0.00 & 0.00 & 0.00 & & \\
\hline V1 & $0.53^{* *}$ & $0.57^{* *}$ & $0.83^{* *}$ & $0.63^{\text {** }}$ & $0.91^{* *}$ & $0.90^{* *}$ & $0.89^{* *}$ & $0.93^{* \prime}$ & $0.81^{*}$ & \\
\hline 0 & 0.00 & 0.00 & 0.00 & 0.00 & 0.00 & 0.00 & 0.00 & 0.00 & 0.00 & \\
\hline
\end{tabular}

2) Reliability of the questionnaire: Cronbach's Alpha test has been computed to analyze the reliability of the questionnaire. Cronbach's Alpha coefficient value of 0.96 in Table 2 indicates that the questionnaire is highly reliable.

\section{Results}

This section presents the findings of the study concerning the students' perception on their competence in performing the activities related to the components of 21 st Century Skills. Further, it discusses the influence of medium of instruction and gender on students' 21 st Century skills.

\section{A. Students' perception of workforce readiness}

1) Creativity and Innovation: According to P21 framework, Creativity and Innovation skills refer to being open and responsive to novel and diverse perspectives for perceptible contribution at the workplace. The descriptive statistics in Table 3 exhibit the students' capability in executing Creativity and Innovation skills. The mean scores of 'Inventing new ideas' $(M=3.28)$, 'Problem Solving' $(M=3.10)$, 'Perception of unusual things' ( $\mathrm{M}=3.52)$, 'Being open and responsive to different aspects' $(\mathrm{M}=3.04)$ and 'Being innovative and developing ideas' $(\mathrm{M}=3.04)$ indicate that the students have perceived them to be in the average level in exhibiting Creativity and Innovation skills. The mean scores of 'Creating' $(\mathrm{M}=2.72)$ and 'Experimenting' $(\mathrm{M}=2.92)$ on new ideas show their assumption of being competent in creating and experimenting on new ideas. This is in contradiction with their own rating as the course of creating and experimenting on new ideas is interconnected to invention, perception, innovation and other aspects of Creativity and Innovation skills. This intimates that the students are inadequate in exhibiting the Creativity and Innovation skills. In the workplace situation, it is essential for the students of engineering and technology to demonstrate Creativity and Innovation as they build new technology like, constructing iconic building, special effects in movies, manufacturing machines and gadgets, developing software and high-tech equipment, etc. Moreover, Kazerounian and Foley (2007) have explored the students' perceptions on the lacunae of creativity in their engineering domain. The Indian engineering education should incorporate Creativity and Innovation skills as is evident from the results in Table 3 implying the need to develop students' novelty and originality of ideas for coping in future workplace situations.

2) Critical Thinking and Problem Solving: P21 framework defines Critical Thinking as the skill required to analyze the parts of interaction for the overall outcome, make judgments and decisions and solve problems. The process of problem solving 
Table 3: Descriptive Statistics on Creativity \& Innovation Skills

\begin{tabular}{|l|c|c|c|c|c|c|c|}
\hline $\begin{array}{l}\text { I am not able } \\
\text { to... }\end{array}$ & $\mathbf{A}$ & $\mathbf{O}$ & $\mathbf{S}$ & $\mathbf{R}$ & $\mathbf{N}$ & $\boldsymbol{M}$ & $\mathbf{S D}$ \\
\hline $\begin{array}{l}\text { Invent new } \\
\text { ideas }\end{array}$ & 20.7 & 27.9 & 21.6 & 18.0 & 11.7 & 3.28 & 1.30 \\
\hline Solve problem & 15.3 & 27.9 & 24.3 & 16.2 & 16.2 & 3.10 & 1.31 \\
\hline $\begin{array}{l}\text { Perceive } \\
\text { unusual things }\end{array}$ & 34.2 & 23.4 & 15.3 & 14.4 & 12.6 & 3.52 & 1.41 \\
\hline $\begin{array}{l}\text { Experiment on } \\
\text { new ideas }\end{array}$ & 17.1 & 25.2 & 16.2 & 15.3 & 26.1 & 2.92 & 1.47 \\
\hline $\begin{array}{l}\text { Be open and } \\
\text { responsive to } \\
\text { different } \\
\text { perspectives }\end{array}$ & 22.5 & 18.0 & 19.8 & 19.8 & 19.8 & 3.04 & 1.45 \\
\hline $\begin{array}{l}\text { Innovate and } \\
\text { develop ideas }\end{array}$ & 22.5 & 18.0 & 19.8 & 19.8 & 19.8 & 3.04 & 1.45 \\
\hline $\begin{array}{l}\text { Create new } \\
\text { ideas }\end{array}$ & 22.5 & 11.7 & 14.4 & 18.0 & 33.3 & 2.72 & 1.57 \\
\hline Overall & $\mathbf{2 2 . 1 1}$ & $\mathbf{2 1 . 7 3}$ & $\mathbf{1 8 . 7 7}$ & $\mathbf{1 7 . 3 6}$ & $\mathbf{1 9 . 9 3}$ & $\mathbf{3 . 0 9}$ & $\mathbf{1 . 4 2}$ \\
\hline
\end{tabular}

Note: $\mathrm{A}=$ Always, $\mathrm{O}=$ Often, $\mathrm{S}=$ Sometimes, $\mathrm{R}=$ Rarely, $\mathrm{N}=$ Never.

involves framing, analyzing and synthesizing information. Table 4 exhibits the students' adequacy level in practicing Critical Thinking and Problem Solving skills. As the mean scores of 'Reasoning' $(\mathrm{M}=2.95)$, 'Questioning' ( $\mathrm{M}=3.23)$, 'Decision making' $(\mathrm{M}=3.19)$, 'Making Judgements' $(\mathrm{M}=2.44)$, 'Analyzing' $(\mathrm{M}=2.92)$ and 'Synthesizing' $(\mathrm{M}=2.24)$ indicate, the students perceive themselves moderate in performing Critical Thinking and Problem Solving skills set, which might be the result of their inaptitude towards judging their skills set. A learning outcome assessment conducted by Stanford University and the World bank have revealed that the students of engineering and technology in India are poor in Higher order thinking skills (Chopra, 2019). Accordingly, the results in Table 4 entail the requirement of students of engineering to improve their Critical Thinking skills facilitating better preparation towards workforce environment.

Table 4 : Descriptive Statistics on Critical Thinking \& Problem Solving

\begin{tabular}{|l|c|c|c|c|c|c|c|}
\hline I am not able to... & $\mathbf{A}$ & $\mathbf{O}$ & $\mathbf{S}$ & $\mathbf{R}$ & $\mathbf{N}$ & $\boldsymbol{M}$ & $\mathbf{S D}$ \\
\hline $\begin{array}{l}\text { Reason out } \\
\text { understanding of } \\
\text { concepts }\end{array}$ & 21.6 & 8.1 & 34.2 & 15.3 & 20.7 & 2.95 & 1.39 \\
\hline $\begin{array}{l}\text { Ask questions to clarify } \\
\text { different views }\end{array}$ & 33.3 & 6.3 & 26.1 & 18.0 & 16.2 & 3.23 & 1.48 \\
\hline $\begin{array}{l}\text { Make complex } \\
\text { decisions }\end{array}$ & 28.8 & 8.1 & 32.4 & 14.4 & 16.2 & 3.19 & 1.42 \\
\hline $\begin{array}{l}\text { Judge the significance } \\
\text { of their ideas }\end{array}$ & 12.6 & 5.4 & 27.0 & 23.4 & 31.5 & 2.44 & 1.33 \\
\hline \begin{tabular}{l} 
Analyze the concepts \\
\hline $\begin{array}{l}\text { Synthesize the } \\
\text { information }\end{array}$
\end{tabular} 28.8 & 2.7 & 25.2 & 18.0 & 25.2 & 2.92 & 1.54 \\
\hline Overall & 10.8 & 2.7 & 27.9 & 17.1 & 41.4 & 2.24 & 1.32 \\
\hline
\end{tabular}

Note: $\mathrm{A}=$ Always, $\mathrm{O}=$ Often, $\mathrm{S}=$ Sometimes, $\mathrm{R}=$ Rarely, $\mathrm{N}=$ Never.
3) Communication: The purpose of communication may vary from informing the data and knowledge to persuade people in pursuit of their work. Hence, Listening, Speaking, Reading, and Writing skills are all represented as Communication skills. The students' discern their proficiency level to be moderate in Communication skills, as evidenced by the overall mean score $(M=3.43)$ in Table 5 exposing the factor that they are 'always' and 'often' not able to maintain coherence, grammar, punctuation, pronunciation, and vocabulary in their Speaking and Writing, in addition to their lacunae in verbal and nonverbal communication during their classroom sessions. Congruently, the study by Srigayathridevi and Thamaraiselvi (2006) has measured the Communication skills of the final year students of engineering resulting in the desideratum to initiate the augmentation of the students' Communication skills. The workplace demands of the communication includes presenting their ideas and updating their progress to their higher authorities through written and oral communication. Similarly, they have to communicate with the clients and be keen in listening to the customers' views and keep record of their work for future reference. The results in Table 5 exhibit that the Communication skills of the students do not meet the requisite workforce demand and will affect their career prospects, as employers expect graduates with proficient Communication skills. In order to overcome this inadequacy, students should be trained strategically and logically on activity-based approach in their classroom.

Table 5:Descriptive Statistics on Communication Skills

\begin{tabular}{|l|l|l|l|l|l|l|l|}
\hline I am not able to... & $\mathbf{A}$ & $\mathbf{O}$ & $\mathbf{S}$ & $\mathbf{R}$ & $\mathbf{N}$ & $\mathbf{M}$ & $\mathbf{S} \boldsymbol{D}$ \\
\hline Organize ideas in writing & 31.5 & 24.3 & 17.1 & 9.0 & 18.0 & 3.42 & 1.47 \\
\hline $\begin{array}{l}\text { Use appropriate Grammar } \\
\text { and Punctuation }\end{array}$ & 20.7 & 28.8 & 20.7 & 14.4 & 15.3 & 3.25 & 1.35 \\
\hline $\begin{array}{l}\text { Understand Pronunciation } \\
\text { and Vocabulary }\end{array}$ & 32.4 & 26.1 & 13.5 & 13.5 & 14.4 & 3.49 & 1.43 \\
\hline Make notes while reading & 33.3 & 25.2 & 17.1 & 11.7 & 12.6 & 3.55 & 1.39 \\
\hline Take notes on lectures & 41.4 & 17.1 & 15.3 & 10.8 & 15.3 & 3.59 & 1.49 \\
\hline Frame questions in English & 24.3 & 24.3 & 18.9 & 12.6 & 19.8 & 3.21 & 1.45 \\
\hline Make mind maps on reading 32.4 & 27.0 & 15.3 & 15.3 & 9.9 & 3.57 & 1.35 \\
\hline $\begin{array}{l}\text { Listen lectures without } \\
\text { distractions }\end{array}$ & 25.2 & 24.3 & 23.4 & 16.2 & 10.8 & 3.37 & 1.31 \\
\hline $\begin{array}{l}\text { Summarize key content of } \\
\text { speaker }\end{array}$ & 21.6 & 27.9 & 20.7 & 16.2 & 13.5 & 3.28 & 1.34 \\
\hline $\begin{array}{l}\text { Generate content fluently } \\
\text { while speaking }\end{array}$ & 28.8 & 20.7 & 28.8 & 12.6 & 9.0 & 3.48 & 1.28 \\
\hline $\begin{array}{l}\text { Maintain eye contact with } \\
\text { audience }\end{array}$ & 34.2 & 20.7 & 22.5 & 9.0 & 13.5 & 3.53 & 1.39 \\
\hline $\begin{array}{l}\text { Exhibit confident body } \\
\text { language }\end{array}$ & 30.6 & 26.1 & 18.0 & 11.7 & 13.5 & 3.49 & 1.39 \\
\hline $\begin{array}{l}\text { Focus on the content of the } \\
\text { speaker }\end{array}$ & 28.8 & 22.5 & 23.4 & 13.5 & 11.7 & 3.43 & 1.35 \\
\hline Overall & $\mathbf{2 9 . 6 3}$ & $\mathbf{2 4 . 2 3}$ & $\mathbf{1 9 . 5 9}$ & $\mathbf{1 2 . 8 1}$ & $\mathbf{1 3 . 6 4}$ & $\mathbf{3 . 4 3}$ & $\mathbf{1 . 3 8}$ \\
\hline
\end{tabular}

Note: $\mathrm{A}=$ Always, $\mathrm{O}=$ Often, $\mathrm{S}=$ Sometimes, $\mathrm{R}=$ Rarely, $\mathrm{N}=$ Never. 
4) Collaboration: Collaboration skill, the capacity to mingle with diverse teams and work effectively will improve the productivity, project management, and greater efficiency in the workplace. It is essential for the students to negotiate and support their group decisions to achieve the shared goals of the group projects. P21 framework insists that the Collaboration skills require flexibility, willingness, and shared responsibility. Table 6 shows the students' perception of their capability in collaborative working to be mediocre concerning 'Fluency during presentation' $(\mathrm{M}=3.41)$, 'Team management' $(\mathrm{M}=2.85)$, 'working effectively in group' $(\mathrm{M}=3.00)$, 'working in different teams' $(\mathrm{M}=3.48)$ and 'leading discussions' $(\mathrm{M}=3.15)$ respectively. Sharing Responsibility involves working effectively in diverse teams, managing team members, and leading them towards target, etc. This explains the misinterpretation of students in rating themselves $\operatorname{good}(\mathrm{M}=2.57)$ in 'sharing

responsibility' along with other Collaboration skills. It might be due to the lack of opportunity to work with different group during their course of graduate studies. Lacuna in fluency could be interpreted as the result of stage fear or fear of audience, lacuna in language proficiency, thinking process, adaptability, etc. Besides, the students have to be competent in leading a discussion or guiding their team members at crucial junctures of project management. Ercan and Khan (2017) have insisted on the need for engineers to be good team players and have presented methods for developing the students' Collaboration skills. Congruently, the results explicate that collaborative tasks should be implemented in the classrooms to hone the students' Collaboration skills.

Table 6 : Descriptive Statistics On Collaboration Skills

\begin{tabular}{|l|c|c|c|c|c|c|c|}
\hline I am not able to... & $\mathbf{A}$ & $\mathbf{O}$ & $\mathbf{S}$ & $\mathbf{R}$ & $\mathbf{N}$ & $\boldsymbol{M}$ & $\boldsymbol{S D}$ \\
\hline Present fluency & 29.7 & 22.5 & 21.6 & 10.8 & 15.3 & 3.41 & 1.41 \\
\hline Manage team & 16.2 & 19.8 & 22.5 & 15.3 & 26.1 & 2.85 & 1.43 \\
\hline Share responsibility & 10.8 & 16.2 & 23.4 & 18.0 & 31.5 & 2.57 & 1.37 \\
\hline $\begin{array}{l}\text { Work with Inter- } \\
\text { department group } \\
\text { projects }\end{array}$ & 17.1 & 24.3 & 20.7 & 17.1 & 20.7 & 3.00 & 1.39 \\
\hline Work in diverse team & 29.7 & 20.7 & 27.9 & 10.8 & 10.8 & 3.48 & 1.31 \\
\hline $\begin{array}{l}\text { Begin and lead } \\
\text { discussions }\end{array}$ & 22.5 & 20.7 & 24.3 & 14.4 & 18.0 & 3.15 & 1.40 \\
\hline Overall & $\mathbf{2 1}$ & $\mathbf{2 0 . 7}$ & $\mathbf{2 3 . 4}$ & $\mathbf{1 4 . 4}$ & $\mathbf{2 0 . 4}$ & $\mathbf{3 . 0 8}$ & $\mathbf{1 . 3 9}$ \\
\hline
\end{tabular}

Note: $\mathrm{A}=$ Always, $\mathrm{O}=$ Often, $\mathrm{S}=$ Sometimes, $\mathrm{R}=$ Rarely, $\mathrm{N}=$ Never

5) Flexibility and Adaptability: Denecke et al., (2009) define Flexibility and Adaptability as "adapting to varied roles and responsibilities" and "working effectively in a climate of ambiguity and changing priorities" (p.7). Table 7 elucidates that the students find it difficult to work in the ambiguous situation $(\mathrm{M}=3.55)$. At the time of priorities being changed, students are often unable to produce effective work as they become puzzled in completing the tasks. The mean value $(\mathrm{M}=3.50)$ of 'Responsibilities' exhibits that the students have not demonstrated responsibility frequently during their course of study. Similarly, they are not prepared to adapt $(\mathrm{M}=3.48)$ to the interchangeable roles in workplace situation. Pulakos et al., (2000) have proclaimed, "fast pace of environmental and organizational change implies heightened pressure on employees to be increasingly adaptable, versatile, and tolerant of uncertainty in order to perform effectively in new or changing work situations" (as cited in Dam, 2013, p. 123). In consonance with this, the results in Table 7 evince the students' indispensable requisite to equip themselves to adapt to the situational needs and demonstrate flexibility accordingly.

Table 7: Descriptive Statistics on Flexibility \& Adaptability

\begin{tabular}{|l|c|c|c|c|c|c|c|}
\hline I am not able to... & $\mathbf{A}$ & $\mathbf{O}$ & $\mathbf{S}$ & $\mathbf{R}$ & $\mathbf{N}$ & $\boldsymbol{M}$ & $\boldsymbol{S D}$ \\
\hline Work in ambiguity & 36.9 & 21.6 & 15.3 & 11.7 & 14.4 & 3.55 & 1.45 \\
\hline Prioritize work & 24.3 & 34.2 & 14.4 & 14.4 & 12.6 & 3.43 & 1.34 \\
\hline Take responsibility & 30.6 & 28.2 & 15.3 & 9.9 & 15.3 & 3.50 & 1.41 \\
\hline Adapt to varied roles & 34.2 & 23.4 & 12.6 & 13.5 & 16.2 & 3.46 & 1.48 \\
\hline Overall & $\mathbf{3 1 . 5}$ & $\mathbf{2 6 . 8 5}$ & $\mathbf{1 4 . 4}$ & $\mathbf{1 2 . 3 8}$ & $\mathbf{1 4 . 6 3}$ & $\mathbf{3 . 4 8}$ & $\mathbf{1 . 4 2}$ \\
\hline
\end{tabular}

Note: $\mathrm{A}=$ Always, $\mathrm{O}=$ Often, $\mathrm{S}=$ Sometimes, $\mathrm{R}=$ Rarely, $\mathrm{N}=$ Never

6) Initiative and Self-Direction: As P21 framework states, goal management, time management, selfmonitoring, defining task, prioritizing, and completing tasks independently, mastery of skills or curriculum for gaining expertise, demonstrating initiative, commitment, and critical reflection on past experiences for better future progress are considered as the attributes of Initiative and Self-Direction skills. The mean values stated in Table 8 indicate the average level of students in 'self-monitoring their own learning and understanding the concepts' $(\mathrm{M}=3.74)$, 'taking initiative towards achieving goal' $(\mathrm{M}=3.54)$, 'exhibiting commitment towards the work' $(\mathrm{M}=3.36)$, 'critically reflecting on their past performance' $(\mathrm{M}=3.52)$, 'finding opportunities to gain expertise beyond their curriculum' $(\mathrm{M}=3.53)$, 'managing their goal towards success' $(\mathrm{M}=3.56)$ and 'prioritizing work according to the time' $(M=3.32)$, i.e., time management. Self-directed learning helps the students to learn new technologies and strategies to work efficiently in projects at their workplace. Though some organizations provide training at the beginning of the career, the students are supposed to learn beyond the curriculum to establish their position 
and unleash their true potential in the workplace. Lemmetty and Collin (2019) assert, "Organisations call for employees' autonomy and self-directedness executed by agile operations and low hierarchies, where learning is also increasingly the responsibility of the individuals and teams themselves and occurs in practice without strong control of the organisation. Therefore, the multidimensional concept of selfdirected learning becomes essential in the context of learning at work" (p. 47). This statement illuminates in addition to the findings in Table 8 that the students should be determined in developing their Initiative and Self-Direction skills to challenge their peer group and be competitive to others.

Table 8: Descriptive Statistics on Initiative \&self-direction

\begin{tabular}{|l|c|c|c|c|c|c|c|}
\hline I am not able to... & $\mathbf{A}$ & $\mathbf{O}$ & $\mathbf{S}$ & $\mathbf{R}$ & $\mathbf{N}$ & $\boldsymbol{M}$ & $\boldsymbol{S D}$ \\
\hline Monitor my learning & 39.6 & 28.8 & 9.0 & 10.8 & 11.7 & 3.74 & 1.39 \\
\hline Demonstrate initiative & 31.5 & 18.9 & 30.6 & 9.9 & 9.0 & 3.54 & 1.28 \\
\hline Keep track of progress & 25.2 & 29.7 & 16.2 & 13.5 & 15.3 & 3.36 & 1.39 \\
\hline $\begin{array}{l}\text { Critically Reflect to past } \\
\text { performance }\end{array}$ & 29.7 & 26.1 & 20.7 & 13.5 & 9.9 & 3.52 & 1.31 \\
\hline $\begin{array}{l}\text { Gain expertise beyond } \\
\text { curriculum }\end{array}$ & 30.6 & 27.0 & 20.7 & 8.1 & 13.5 & 3.53 & 1.36 \\
\hline Find resources & 30.6 & 30.6 & 15.3 & 10.8 & 12.6 & 3.56 & 1.36 \\
\hline $\begin{array}{l}\text { Complete my work } \\
\text { within the given time }\end{array}$ & 28.8 & 24.3 & 14.4 & 14.4 & 18.0 & 3.32 & 1.48 \\
\hline Overall & $\mathbf{3 0 . 8 6}$ & $\mathbf{2 6 . 4 9}$ & $\mathbf{1 8 . 1 3}$ & $\mathbf{1 1 . 5 7}$ & $\mathbf{1 2 . 8 6}$ & $\mathbf{3 . 5 1}$ & $\mathbf{1 . 3 7}$ \\
\hline
\end{tabular}

Note: $\mathrm{A}=$ Always, $\mathrm{O}=$ Often, $\mathrm{S}=$ Sometimes, $\mathrm{R}=$ Rarely, $\mathrm{N}=$ Never

7) Social and Cross-Cultural skills: Social and CrossCultural skills enable the students to bridge cultural differences and to use different perspectives of other social and cultural group thereby fostering the innovation skill and improving the quality of work. It leverages the collective intelligence of group at appropriate situation (Denecke et al., 2009). The mean value $(M=3.68)$ in Table 9 shows the students' perception on their inadequacy to work productively in different social or cultural group, besides stating that they 'always' and 'often' do not bridge cultural differences among their group (M=3.28). Mean scores of 'Connecting different perspectives' $(\mathrm{M}=3.64)$ and 'Working with social and cross-cultural group' $(M=3.44)$ signify that the students find it difficult to assimilate different points of views of other social and cultural group, apart from being diffident in working with such groups. Stefanenko and Kupavskaya (2012) have emphasized, "High interactivity and technological advancement of the modern world stimulates rapid and efficient interaction between cultures" (p. 942). This is in consensus with the results of Table 9 on the need for the students of engineering and technology to possess social and cross-cultural skills as they must work for the customers across the globe.

\section{Table 9: Descriptive Statistics On Social \& Cross-cultural Skills}

\begin{tabular}{|l|c|c|c|c|c|c|c|}
\hline I am not able to... & $\mathbf{A}$ & $\mathbf{O}$ & $\mathbf{S}$ & $\mathbf{R}$ & $\mathbf{N}$ & $\boldsymbol{M}$ & $\boldsymbol{S D}$ \\
\hline $\begin{array}{l}\text { Work } \\
\text { productively in } \\
\text { group }\end{array}$ & 38.7 & 26.1 & 15.3 & 3.6 & 16.2 & 3.68 & 1.43 \\
\hline $\begin{array}{l}\text { Bridge cultural } \\
\text { differences }\end{array}$ & 24.3 & 23.4 & 23.4 & 13.5 & 15.3 & 3.28 & 1.38 \\
\hline $\begin{array}{l}\text { Connect different } \\
\text { perspectives }\end{array}$ & 36.9 & 24.3 & 15.3 & 12.6 & 10.8 & 3.64 & 1.37 \\
\hline $\begin{array}{l}\text { Work with Social } \\
\text { and cross-cultural } \\
\text { group }\end{array}$ & 31.5 & 22.5 & 20.7 & 9.0 & 16.2 & 3.44 & 1.43 \\
\hline Overall & $\mathbf{3 2 . 8 5}$ & $\mathbf{2 4 . 0 8}$ & $\mathbf{1 8 . 6 8}$ & $\mathbf{9 . 6 8}$ & $\mathbf{1 4 . 6 3}$ & $\mathbf{3 . 5 1}$ & $\mathbf{1 . 4 0}$ \\
\hline
\end{tabular}

Note: $\mathrm{A}=$ Always, $\mathrm{O}=$ Often, $\mathrm{S}=$ Sometimes, $\mathrm{R}=$ Rarely, $\mathrm{N}=$ Never.

8) Productivity and Accountability: Productivity and accountability skills encompass goal setting, stress management, planning and managing work to achieve the target, positive work ethics, project management, multi-tasking, active participation, reliability, punctuality, self-representation, and diligence. The overall mean value $(\mathrm{M}=3.53)$ in Table 10 suggests that the students have rated themselves tenuous in 'Goal setting' ( $M=3.76)$, 'Exhibiting punctuality' $(M=3.45)$ 'Reliability' ( $\mathrm{M}=3.50)$ and they are not good in 'taking responsibility and performing the projects with confidence' $(\mathrm{M}=3.41)$. Lack of accountability will deprive students' focus on the work details, and will spoil their scheduled work shattering their honesty and liability among their peers and colleagues, besides refraining them from doing the job. Kelly (2018) has established the concurrence between accountable performance of employees and the productivity of the organization and Trivedi (2013) has insisted, "A lack of individual accountability is a common cause of low employee morale which leads to reduced productivity, poor organizational performance, and increased employee turnover" (p. 1). It is deciphered from these statements and from the results in Table 10 that there is a necessity to equip the students of engineering to develop Productivity and Accountability skills and be prepared with the tenets of the workforce requirement.

Table 10: Descriptive Statistics on Productivity \& Accountability

\begin{tabular}{|l|c|c|c|c|c|c|c|}
\hline I am not able to... & $\mathbf{A}$ & $\mathbf{O}$ & $\mathbf{S}$ & $\mathbf{R}$ & $\mathbf{N}$ & $\boldsymbol{M}$ & $\boldsymbol{S D}$ \\
\hline Set standard goals & 39.6 & 25.2 & 16.2 & 9.0 & 9.9 & 3.76 & 1.33 \\
\hline Exhibit punctuality & 31.5 & 26.1 & 14.4 & 11.7 & 16.2 & 3.45 & 1.45 \\
\hline Manage projects & 30.6 & 24.3 & 17.1 & 10.8 & 17.1 & 3.41 & 1.45 \\
\hline $\begin{array}{l}\text { Be reliable among } \\
\text { classmates }\end{array}$ & 39.6 & 18.0 & 14.4 & 8.1 & 19.8 & 3.50 & 1.55 \\
\hline Overall & $\mathbf{3 5 . 3 3}$ & $\mathbf{2 3 . 4}$ & $\mathbf{1 5 . 5 3}$ & $\mathbf{9 . 9}$ & $\mathbf{1 5 . 7 5}$ & $\mathbf{3 . 5 3}$ & $\mathbf{1 . 4 5}$ \\
\hline
\end{tabular}

Note: $\mathrm{A}=$ Always, $\mathrm{O}=$ Often, $\mathrm{S}=$ Sometimes, $\mathrm{R}=$ Rarely, $\mathrm{N}=$ Never. 
9) Leadership and Responsibility: Leadership skill requires interpersonal skills and Problem Solving skills to influence and guide others to achieve a common goal. A leader should leverage strength of his/her teammates to accomplish the target. P21 (2009) defines responsibility as acting "responsible with the interests of the larger community in mind". As Table 11 indicates, the mean scores of 'influencing and guiding others' $(\mathrm{M}=3.59)$, 'taking responsibility keeping the larger community in mind' $(\mathrm{M}=3.52)$, 'maintaining unity among the group' $(\mathrm{M}=3.68)$, 'exhibiting integrity' $(\mathrm{M}=3.52)$ and being ready to 'accept criticism' $(\mathrm{M}=3.56)$ bespeak that the students have regarded themselves as mediocre in Leadership and Responsibility skills set. This skills set will help the students to accomplish common goals with support of their team members at their workplace engendering them to aspire and step up the career ladder as leaders and pursue their responsibilities. Further, Farr and Brazil (2009) have discerned that the young engineers have to enhance their leadership skills to succeed in their workplace as the change in global environment impacts the nature of modern engineering and have provided a set of framework for the students of engineering to develop their leadership qualities. It is deciphered that the students of engineering and technology should enhance their Leadership and Responsibility skills set to guide their team members in the right path to be responsible at their workplace and to grow in their career ladder.

\section{Table 11: Descriptive Statistics on} Leadership \& Responsibility

\begin{tabular}{|l|c|c|c|c|c|c|c|}
\hline I am not able to... & $\mathbf{A}$ & $\mathbf{O}$ & $\mathbf{S}$ & $\mathbf{R}$ & $\mathbf{N}$ & $\boldsymbol{M}$ & $\boldsymbol{S D}$ \\
\hline $\begin{array}{l}\text { Influence and guide others } \\
\begin{array}{l}\text { Be leader and take } \\
\text { responsibility }\end{array}\end{array}$ & 28.3 & 23.4 & 21.6 & 11.7 & 9.9 & 3.59 & 1.32 \\
\hline $\begin{array}{l}\text { Maintain unity among the } \\
\text { teammates }\end{array}$ & 39.6 & 26.1 & 10.8 & 9.9 & 13.5 & 3.68 & 1.43 \\
\hline Exhibit Integrity & 30.6 & 27.0 & 19.8 & 9.0 & 13.5 & 3.52 & 1.37 \\
\hline Accept criticism positively & 32.4 & 25.2 & 19.8 & 10.8 & 11.7 & 3.56 & 1.35 \\
\hline Overall & $\mathbf{3 2 . 9 4}$ & $\mathbf{2 5 . 9 2}$ & $\mathbf{1 9 . 2 6}$ & $\mathbf{9 . 1 8}$ & $\mathbf{1 2 . 6}$ & $\mathbf{3 . 5 7}$ & $\mathbf{1 . 3 6}$ \\
\hline
\end{tabular}

Note: $\mathrm{A}=$ Always, $\mathrm{O}=$ Often, $\mathrm{S}=$ Sometimes, $\mathrm{R}=$ Rarely, $\mathrm{N}=$ Never.

B. Overall perception of Students' workplace preparedness

Table 12 presents the descriptive analysis of students' outlook on their preparedness in exhibiting Learning and Innovation skills, and Life and Career skills. The overall mean score of Learning and Innovation skills ranges between 2.83 and 3.43; whereas, the overall mean score of Life and Career skills ranges between 3.48 and 3.57. It reveals the students' assertion of being highly inadequate in demonstrating Life and
Career skills in comparison with their potential to exhibit Learning and Innovation skills. This might be the result of frequent usage of the terms 'Creativity,' 'Communication,' 'Collaboration,' etc., by teachers and peers in the academic environment and the lack of acquaintance with the terms concerning Life and Career skills. Yet, it is evident from the overall perception of the students' preparedness, that there exists a need for the implementation of these $21 \mathrm{st}$ Century skills set in the engineering curriculum for their better career prospects.

Table 12: Overall Mean of the Descriptive Statistics on 21st Century Skills Set

\begin{tabular}{|l|l|c|c|}
\hline & $\mathbf{2 1}^{\text {st }}$ Century Skills & $\boldsymbol{M}$ & $\boldsymbol{S D}$ \\
\hline \multirow{4}{*}{$\begin{array}{l}\text { Learning and } \\
\text { Innovation skills }\end{array}$} & Creativity \& Innovation & 3.09 & 1.42 \\
\cline { 2 - 4 } & & 2.83 & 1.41 \\
\cline { 2 - 4 } & Critical Thinking & 3.43 & 1.38 \\
\cline { 2 - 4 } & Communication & 3.08 & 1.39 \\
\cline { 2 - 4 } Life and Career \\
skills & Flexibility \& Adaptability & 3.48 & 1.42 \\
\cline { 2 - 5 } & Initiative \& Self-Direction & 3.51 & 1.37 \\
\cline { 2 - 5 } & Social \& Cross-Cultural Skills & 3.51 & 1.40 \\
\cline { 2 - 5 } & Productivity \& Accountability & 3.53 & 1.45 \\
\cline { 2 - 5 } & Leadership \& Self-Direction & 3.57 & 1.36 \\
\hline
\end{tabular}

\section{Impact of Gender:}

The significant values of Shapiro-Wilk test greater than 0.05 in Table 13 exhibit that the data is normally distributed.

Table 13: Normality Test For Gender

\begin{tabular}{|l|l|l|}
\hline & Gender & Shapiro-Wilk \\
\hline \multirow{2}{*}{ Creativity } & Male & 0.25 \\
\cline { 2 - 3 } & Female & 0.08 \\
\hline \multirow{2}{*}{ Critical Thinking } & Male & 0.38 \\
\cline { 2 - 3 } & Female & 0.43 \\
\hline Communication & Male & 0.91 \\
\cline { 2 - 3 } & Female & 0.23 \\
\hline Collaboration & Male & 0.71 \\
\cline { 2 - 3 } & Female & 0.81 \\
\hline Productivity \& Accountability & Male & 0.48 \\
\cline { 2 - 3 } & Female & 0.21 \\
\hline Leadership \& Responsibility & Male & 0.47 \\
\cline { 2 - 3 } & Female & 0.19 \\
\hline Social \& Cross Cultural & Male & 0.08 \\
\cline { 2 - 3 } & Female & 0.06 \\
\hline Initiative \& Self-Direction & Male & 0.09 \\
\cline { 2 - 3 } & Female & 0.07 \\
\hline Flexibility \& Adaptability & Male & 0.10 \\
\cline { 2 - 3 } & Female & 0.41 \\
\hline
\end{tabular}

Independent samples t-test has been computed to analyze the impact of gender on students' skills set. A study by Horrell, Rubery and Burchell (1990) reveals that there is a difference between the perceptions of men and women on "the skills required in their jobs, 
with women emphasizing personal and social skills, and in the level of skill involved" (p. 189). On the contrary, $p>0.05$ in Table 14 exhibits that there is no difference between gender and the students' skills set implying the insignificant effect of gender on the acquisition of 21 st Century skills except Critical Thinking and Problem Solving. $\mathrm{p}<0.05$ in Table 14 demonstrates that the perception of students on Critical Thinking and Problem Solving skills differs with respect to gender. In congruence with this result, Shubina and Kulakli (2019) have stated the significant difference between male and female in Critical Thinking, where females have scored higher than males in some of the Critical Thinking scales. Further, the overall mean values of gender in Table 14 indicates the prominence of the female students $(\mathrm{M}=3.27)$ in employing 21st Century skills than male students.

Table 14 : Independent Samples T-test Between Gender And 21st Century Skills Set

\begin{tabular}{|l|c|c|c|c|c|c|}
\hline 21 $^{\text {st }}$ Century Skills & \multicolumn{2}{|c|}{$\begin{array}{c}\text { Male } \\
(\mathbf{n}=\mathbf{6 7})\end{array}$} & \multicolumn{2}{c|}{$\begin{array}{c}\text { Female } \\
(\mathbf{n = 4 4 )}\end{array}$} & \multirow{2}{*}{$\boldsymbol{p}$} \\
\cline { 2 - 6 } & $\mathbf{M}$ & $\mathbf{S D}$ & $\mathbf{M}$ & $\mathbf{S D}$ & & \\
\hline Creativity & 3.04 & 0.78 & 2.95 & 0.92 & 0.54 & 0.59 \\
\hline Critical Thinking & 3.02 & 0.74 & 2.53 & 0.98 & 2.88 & 0.01 \\
\hline Communication & 3.32 & 0.81 & 3.44 & 1.19 & -0.60 & 0.55 \\
\hline Collaboration & 3.05 & 0.82 & 3.11 & 1.09 & -0.33 & 0.74 \\
\hline Flexibility \& Adaptability & 3.51 & 1.11 & 3.44 & 1.34 & 0.28 & 0.78 \\
\hline $\begin{array}{l}\text { Initiative \& Self-Direction } \\
\text { Social \& Cross-Cultural } \\
\text { Skills }\end{array}$ & 3.54 & 1.04 & 3.46 & 1.26 & 0.351 & 0.73 \\
\hline $\begin{array}{l}\text { Productivity \& } \\
\text { Accountability }\end{array}$ & 3.54 & 1.09 & 3.47 & 1.38 & 0.29 & 0.77 \\
\hline Leadership \& Responsibility & 3.57 & 0.99 & 3.56 & 1.37 & 0.06 & 0.95 \\
\hline Average mean score & $\mathbf{3 . 3 5}$ & 0.95 & $\mathbf{3 . 2 7}$ & 1.22 & & \\
\hline
\end{tabular}

\section{Influence of Medium of Instruction:}

Table 15 demonstrates the significant values of the Shapiro-Wilk test being greater than 0.05 implying the normal distribution of the data.

Independent samples t-test has been computed to identify the influence of medium of instruction on students' 21 st Century skills set. $p>0.05$ in Table 16 indicate that there is no significant difference between the medium of instruction and the students' skills set. $\mathrm{p}=0.01$ in Table 16 indicates the significant difference between medium of instruction and Critical Thinking and Problem Solving skills. It implies that the medium of instruction has impact on the acquisition of students' skills set except for Critical Thinking and
Table 15 : Normality Test For Medium Of Instruction

\begin{tabular}{|l|l|l|}
\hline Skills & $\begin{array}{l}\text { Medium of } \\
\text { Instruction }\end{array}$ & $\begin{array}{l}\text { Shapiro- } \\
\text { Wilk }\end{array}$ \\
\hline \multirow{2}{*}{ Creativity } & English & 0.56 \\
\cline { 2 - 3 } & Mother Tongue & 0.87 \\
\hline Critical Thinking & English & 0.75 \\
\cline { 2 - 3 } & Mother Tongue & 0.26 \\
\hline \multirow{2}{*}{ Communication } & English & 0.05 \\
\cline { 2 - 3 } & Mother Tongue & 0.07 \\
\hline \multirow{2}{*}{ Collaboration } & English & 0.08 \\
\cline { 2 - 3 } & Mother Tongue & 0.08 \\
\hline \multirow{2}{*}{ Productivity \& Accountability } & English & 0.86 \\
\cline { 2 - 3 } & Mother Tongue & 0.09 \\
\hline \multirow{2}{*}{ Social \& Cross Cultural } & English & 0.06 \\
\cline { 2 - 3 } & Mother Tongue & 0.11 \\
\hline \multirow{2}{*}{ Initiative \& Self-Direction } & English & 0.40 \\
\cline { 2 - 3 } & Mother Tongue & 0.33 \\
\hline \multirow{2}{*}{ Flexibility \& Adaptability } & English & 0.21 \\
\cline { 2 - 3 } & Mother Tongue & 0.15 \\
\hline & English & 0.16 \\
\cline { 2 - 3 } & Mother Tongue & 0.07 \\
\hline
\end{tabular}

Problem Solving. Cahit (2019) has stated "language skills and critical thinking skills are concepts that affect each other in a positive and direct way". In this regard, the exposure and foreign language learning of students from English medium of instruction succor them in exhibiting Critical Thinking skills in contradiction to the students from Mother Tongue medium of instruction with constraints in manifesting their Critical Thinking skills set. The comprehensive results of independent samples t-test explicate the preparedness of the students of engineering and technology from English medium and Mother Tongue medium of instructions being consistent in exposing their 21 st Century Skills set.

Table 16: Independent Samples T-test Between Medium of Instruction And 21 st Century Skills Set

\begin{tabular}{|c|c|c|c|c|c|c|}
\hline Skills & $\begin{array}{l}\text { Medium of } \\
\text { Instruction }\end{array}$ & $\mathbf{N}$ & M & SD & $t$ & $p$ \\
\hline \multirow[t]{2}{*}{ Creativity } & English & 62 & 2.88 & 0.84 & \multirow{2}{*}{-1.79} & \multirow{2}{*}{0.07} \\
\hline & Mother Tongue & 49 & 3.17 & 0.81 & & \\
\hline \multirow[t]{2}{*}{ Critical Thinking } & English & 62 & 2.63 & 0.92 & \multirow{2}{*}{-2.81} & \multirow{2}{*}{0.01} \\
\hline & Mother Tongue & 49 & 3.08 & 0.75 & & \\
\hline \multirow[t]{2}{*}{ Communication } & English & 62 & 3.34 & 1.07 & \multirow{2}{*}{-0.39} & \multirow{2}{*}{0.70} \\
\hline & Mother Tongue & 49 & 3.41 & 0.85 & & \\
\hline \multirow[t]{2}{*}{ Collaboration } & English & 62 & 2.95 & 0.96 & \multirow{2}{*}{-1.65} & \multirow{2}{*}{0.10} \\
\hline & Mother Tongue & 49 & 3.23 & 0.88 & & \\
\hline \multirow{2}{*}{$\begin{array}{l}\text { Flexibility and } \\
\text { Adaptability }\end{array}$} & English & 62 & 3.40 & 1.17 & \multirow{2}{*}{-0.80} & \multirow{2}{*}{0.43} \\
\hline & Mother Tongue & 49 & 3.59 & 1.25 & & \\
\hline \multirow{2}{*}{$\begin{array}{l}\text { Initiative and Self- } \\
\text { Direction }\end{array}$} & English & 62 & 3.44 & 1.12 & \multirow{2}{*}{-0.73} & \multirow{2}{*}{0.47} \\
\hline & Mother Tongue & 49 & 3.60 & 1.14 & & \\
\hline \multirow{2}{*}{$\begin{array}{l}\text { Social and Cross- } \\
\text { Cultural skills } \\
\end{array}$} & English & 62 & 3.48 & 1.22 & \multirow{2}{*}{-0.25} & \multirow{2}{*}{0.81} \\
\hline & Mother Tongue & 49 & 3.54 & 1.21 & & \\
\hline \multirow{2}{*}{$\begin{array}{l}\text { Productivity and } \\
\text { Accountability }\end{array}$} & English & 62 & 3.51 & 1.24 & \multirow{2}{*}{-0.14} & \multirow{2}{*}{0.89} \\
\hline & Mother Tongue & 49 & 3.55 & 1.38 & & \\
\hline \multirow{2}{*}{$\begin{array}{l}\text { Leadership and } \\
\text { Responsibility }\end{array}$} & English & 62 & 3.58 & 1.12 & \multirow{2}{*}{0.10} & \multirow{2}{*}{0.92} \\
\hline & Mother Tongue & 49 & 3.56 & 1.19 & & \\
\hline
\end{tabular}




\section{Discussion}

Skills gap in the engineering sectors declines the scope of employment for the engineering graduates. India produces large number of engineers among other countries of the world, but the National Employability report of 2016 by Aspiring Minds have stated that only seven percent of engineers are suitable for core engineering jobs (as cited in Srividhya and Vijayakumari, 2017). Hence, it is essential to analyze the level of the students' skills set for fostering their competence and preparing them as work ready individuals. In this regard, the present study examines the preparedness of the students of engineering and technology for their workplace demands. The 21st Century skills are requisite to meet the challenges of the global workforce. AMA (2019) has stated that the employers expect 21st Century skills from their workforce to succeed in the competitive edge in the world of work. A study by Microsoft Partners in Learning and the Pearson Foundation (2013) has identified that developing 21 st Century skills among the students have increased the quality of work. Congruently, the present study has analyzed the students' perception towards Learning and Innovation skills and Life and Career skills and has discovered the importance of employing 21st Century skills across the engineering curriculum.

In India, the government has taken initiatives to develop the skills set of students but the focus on the students' level of competence has been ignored unaware of the significance of perusing students' needs in enhancing their skills set. In this line, the present study has explored the students' potential with regard to 21 st Century skills and has identified the inadequacy in the students' skills set as evident in Table 10. The results have necessitated the need to improve students' skills set and has eventually attested the imperativeness of integrating 21st Century skills in the engineering curriculum. Schuller (2011) has stated "Women are now outperforming men at every level in the education system" (p.vi). In concord with this, the study has analyzed the influence of gender on students' perceptions towards the 21 st Century skills. The results in Table 14 have asserted no ascendancy of female students towards the skills acquisition in comparison with male students. Congruently, Aluko (2014) has identified "the structure of the labour market were increasingly seen as having to be negotiated by individual graduates through the use of their agency and other personal resources and not gender"(p. 102). Hence, irrespective of gender, the students are to be facilitated with the 21 st Century skills to achieve success in their career.
Medium of instruction plays a crucial role in the teaching and learning process. Hence, the study has investigated the possibilities of medium of instruction influencing the students' competence of 21 st Century skills. The results in Table 16 have disclosed that there is no difference between the students from English medium of instruction and Mother Tongue medium of instruction pertaining to the students' competence in exerting the 21 st Century skills. It implies that the language of instruction is not an obstacle for the students to develop the skills set.

It is conspicuous that $\mathrm{P} 21$ framework encompasses the overall tenets of the skills set entailed in the 21st Century workplace. The constructs of Learning and Innovation skills and Life and Career skills tabulated in the present study will be obliging to the workplace needs of the students of engineering and technology and the teachers should employ it in their teaching methodologies for capacitating the students' potential and empower them in the world of work. Fandino (2013) has suggested integrating 21st Century skills with English language classroom quoting different frameworks of the North Central Regional Educational Laboratory (NCREL) and Assessment and Teaching of 21st Century skills (ATC21s) to promote the skills of the students in Colombia. Lichtenegger (2014) has revealed that the teaching methods and approaches of Partnership for 21st Century skills is 'highly relevant and applicable' in EFL context and has exhorted the teachers of English to implement these skills in their classroom. In this line, further study could focus on designing a teaching module incorporating these tenets of P21 framework and integrating 21st Century skills in the English classroom to augment the skills set of the students of engineering and technology.

\section{Implementation}

"Today's job market in India is quite demanding and challenging that the engineering graduates are expected to possess employable qualities when they appear for job interviews" (Clement and Murugavel, 2015, p.116). It is evident from the present study that the students of engineering and technology are not prepared to meet the challenges in the workplace. Correspondingly, the study proposes to integrate these skills in the engineering curriculum especially in English language classroom to lubricate the acquisition of 21 st Century skills along with language skills. The LSRW skills of the students are developed through variegated skill-based activities say, group discussions, presentations, role plays, etc. 
Congruently, the amalgamation of 21 st Century skills and LSRW skills would benefit the teachers in instigating the students' skills set. English teachers can use and coalesce different pedagogical approaches and methods like Problem-based approach, Project-based approach, Collaborative teaching method and task-based approach in their classroom to augment language skills and $21 \mathrm{st}$ Century skills. As second language learners of English, the students of engineering and technology in India has to improve their language proficiency to demonstrate their skill in the global platform. Hence, assimilating 21st Century skills in the English language teaching-learning process would profoundly impact the students' skill development to boost their career and work-related goals.

\section{Conclusion}

The persisting skills gap between the industry requirement and students' skills set are discussed in many studies from the perspectives of employers and policy makers. In addition, the educational departments of India are still thriving to develop the skills set of the students by training the teachers. But the students' perception towards their skills pertaining to 21 st Century skills has been left unexplored in India. It is desideratum to understand the students' skills set before developing strategies to enhance their skills set. Accordingly, this study has examined the level of 21 st Century skills competence possessed by the students of engineering and technology. Further, it has discovered the inadequacy in the students' skills set as perceptible from the results. It is imperative for the students to improve these skills set in order to flourish in their profession. To prepare the students for workforce, the study recommends the experts and researchers to develop a module on 21 st Century skills in the engineering curriculum as the present study has confined itself to explore on the students' needs. Further, the paper suggests efficacious integration of these skills in the pedagogy of English language teachers in engineering colleges. The study staunchly posits the pedagogical intervention and reinforcement of 21 st Century skills in the classroom situation for impeccable preparedness of the students of engineering and technology to be work ready in this globalized context.

\section{Reference}

[1] Aluko, Y.A. (2014) Gender Influence on Potential Graduates Perceptions of the Importance of Employability Skills: An
Exploratory Study, East African Journal of Educational Research and Policy, 10, 83-106.

[2] AMA. (2019) AMA Critical Skills Survey: Workers Need Higher level Skills to succeed in the 21st Century, Retrieved August 2, 2020, from https://www.amanet.org/articles/ama-criticalskills-survey-workers-need-higher-level-skillsto-succeed-in-the-21st-century/

[3] Aspiring Minds. (2016), National Employability Report: Engineers. Retrieved August 2, 2020, from https://www.aspiringminds.com/researchreports/national-employability-report-forengineers-2016/

[4] Bhola, S. S. and Dhanawade, S.S. (2013). doi:10.2139/ssrn.2290103

[5] Cahit, E. (2019) A Review on the Relationship between Critical Thinking Skills and Learning Domains of Turkish Language, Educational Research and Reviews, 14 (3), 66-77. doi: 10.5897/ERR2018.3658

[6] Casner-Lotto, J. and Barrington, L. (2006) Are They Really Ready to Work? Employers' Perspectives on the Basic Knowledge and Applied Skills of New Entrants to the 21st Century US Workforce, Retrieved August 2, 2020 from https://eric.ed.gov/?id=ED519465

[7] Chopra, R. (2019, 4 April) Indian Engineering students gain in first two years, high-order thinking is poor': Study, Indian Express, Retrieved August 2, 2020 , from https://indianexpress.com/article/education/indi an-engineering-students-gain-in-first-twoyears-high-order-thinking-is-poor-study$5122475 /$

[8] Chu, S. K W., Reynolds, R. B., Travares, N. J., Notari, M. and Lee, C. W. Y. (2017), 21st Century skills Development through InquiryBased learning: From Theory to Practice, Springer Science+Business Media, Singapore.

[9] Clement, A and Murugavel, T. (2015) English for Employability: A Case Study of the English Language Training Need Analysis for Engineering Students in India, English Language Teaching, 8(2), 116-125.

[10] Dam, V. K. (2013), Employee adaptability to 
change at work: A multidimensional, resourcebased framework, in The Psychology of Organizational Change: Viewing Change from the Employee's Perspective, Cambridge University Press, Cambridge, pp. 123-142.

[11] Dede, Chris. (2009), Comparing Frameworks for "21st Century Skills", in 21st Century Skills: Rethinking how Students Learn, Solution Tree Press, Bloomington, IN, pp. 51-76.

[12] Denecke, D., Justice, K., Magenheim, A. Parkhouse, M., Telford, S., Vanderlinde, G. and Kramer, S. (2009), 21st Century Skills, April 16, 2009, Madeira City Schools Planning Commission, Retrieved August 2, 2020, from https://www.madeiracityschools.org/docs/21st $\% 20$ Century $\% 20$ Report $\% 20$ with $\% 20$ Appendic es.pdf

[13] Egnor, G. P. (2013), A Case Study of 21st Century Skills in High Achieving Elementary Schools in Pennsylvania (Doctoral Dissertation), Retrieved August 2, 2020, from https://search.proquest.com/docview/13527532 31

[14] Ercan, M. F. and Khan, R. (2017) Teamwork as a fundamental Skill for engineering graduates, 2017 IEEE International Conference on Teaching, Assessment, and Learning for Engineering, The Education University of Hong Kong, 12-14 December 2017.

[15] Esponda, F. and Guerrero, V. M. (2009) Surveys with Negative Questions for Sensitive Items. Statistics and Probability Letters, 79 (24), 24562461.

[16] Fandino, Y.J. (2013) 21st Century Skills and the English Foreign Language Classroom: A Call for More Awareness in Colombia, Gist Education and Learning Research Journal, 7, 190-208.

[17] Farr, J. V. and Brazil, D. M. (2009) Leadership Skills Development for Engineers, Engineering Management Journal, 21 (1), 3-8.

[18] Horrell,S., Rubery, J. and Burchell, B. (1990) Gender and Skills, Work, Employment \& Society, 4 (2), 189-216.

[19] Kazerounian, K and Foley, S. (2007) Barriers to
Creativity in Engineering Education: A Study of Instructors and Students Perceptions, Journal of Mechanical Design, 129, 761-768.

[20] Kelly, T. N. N. (2018) Accountability and Employee Performance, Central University of Applied Sciences, Kokkola, Finland.

[21] Lemmetty, S. and Collin, K. (2019) SelfDirected Learning as a Practice of Workplace Learning: Interpretative Repertoires of SelfDirected Learning in ICT Work, Vocations and Learning, 13, 47-70. doi: 10.1007/s12186-01909228-x

[22] Lichtenegger, B. (2014) 21st Century SkillsStatus Quo in Austrian HLW EFL Classrooms and Implications for Teaching (M.Phil. Dissertation), Retrieved August 2, 2020 from http://othes.univie.ac.at/33173/

[23] McLachlan, K. (2012), A Case Study of 21st Century Skills Programs and Practices (Doctoral dissertation), Retrieved August 2, 2020 from http://digitallibrary.usc.edu/cdm/ref/collection/ p15799coll3/id/3094

[24] Microsoft Partners in Learning and the Pearson Foundation (2013), 21st Century Skills and the Workplace: A 2013 Microsoft Partners in Learning and Pearson Foundation Study, Gallup, Washington, DC.

[25] Morell, L. (2010) Engineering Education in the 21st Century: Roles, Opportunities and Challenges, International, Journal of Technology and Engineering Education, 7 (2), 110.

[25] National Skill Development Corporation (2007), Human Resource and Skills Requirements in the IT and ITeS Sector (2013-17, 2017-22), KPMG Advisory Services Pvt Ltd, Retrieved August 2, 2020 from https://nsdcindia.org/sites/default/ files/IT-and-ITeS.pdf

[26] Oliver, B. (2016, December) Strategies that Promotes 21st Century Skills, Just for the Asking, Retrieved August 2, 2020 from https://justaskpublications.com/just-askresource-center/e-newsletters/just-for-theasking/strategies-that-promote-2 1 st-centuryskills/ 
[27] P21 (Partnership for 21 st Century Skills) (2009), P21 Framework Definitions, Retrieved August 2, 2020 from https://files.eric.ed.gov/fulltext/ ED519462.pdf

[28]PeopleStrong, Wheebox, CII, Pearson, AIU, AICTE and UNDP (2018), India Skills Report 2018, Retrieved August 2, 2020 from https://www.peoplestrong.com/wpcontent/uploads/2019/08/ISR_2018_FullVersio n.pdf

[29] Ramanan, L., Kumar, M. and Ramanakumar, K.P.V. (2015) Approach Towards Reducing Soft Skill Gap of Engineering Graduates in India from Employers' Perspective to Employability, International Journal of Engineering Research Online, 3 (6), 504-512.

[30]Robbins, K. (2017) 21st Century Skills: Student Readiness, Opportunities, and Development (Master's Thesis), Retrieved August 2, 2020 from http://thescholarship.ecu.edu/handle/ $10342 / 6121$

[31] Samavedham, L. and Ragupathi, K. (2012) Facilitating 21st Century Skills in Engineering Students, The Journal of Engineering Education, 26(1), 37-49.

[32] Schuller, T. (2011), Gender and Skills in a Changing Economy, UK Commission for Employment and Skills, Longview, Retrieved A u g u s t 2, 2020 f r o m http://dera.ioe.ac.uk/10463/1/equalitygender.pdf

[33] Shubina, I. and Kulakli, A. (2019) Critical Thinking, Creativity and Gender Difference for Knowledge Generation in Education, Literacy Information and Computer Education Journal, $10(1), 3086-3093$.

[34] Sloka, et al. (2015) Employers' Needs and Expectations for Qualified Employees (Case Study on the Opinions in one of the Regions of Latvia), Economics and Business, 27, 69-75. doi: 10.1515/eb-2015-0011
[35] Soltis, L. and Hastings, M. (2017), 2017 Workforce Needs Survey: A Survey of Employers in the Roanoke Region of Virginia, Retrieved from August 2, 2020 https://virginiawestern.edu/cte/docs/2017Workf orceNeedsSurvey.pdf

[36] Srigayathridevi, K. and Thamaraiselvi, R. (2006) Communications Skills among the Final Year Engineering Students in an Autonomous Engineering College in Coimbatore, India: an Evaluation, The Journal of Nepalese Business Studies, III(1), 114-119.

[37]Srividhya and Vijayakumari, D. G. (2017) Employability Trends of Engineering Graduates in Tamil Nadu, Economics, 3 (6), 65-66.

[38 ]Stefanenko, T. and Kupavskaya, A. (2012), Developing Cross-cultural Competence, in Encyclopedia of the Sciences of Learning, S p r i n ger, B o s t o n, M A. d o i : https://doi.org/10.1007/978-1-4419-14286_1818

[39] Sural, I. (2017) 21st Century Skills Level of Teacher Candidates, European Journal of Education Studies, 3 (8), 530 - 538. doi: http://dx.doi.org/10.46827/ejes.v0i0.949

[40] Suto, I. (2013) 21st Century Skills: Ancient, Ubiquitous, Engimatic? Research Matters: A Cambridge Assessment Publication, (15), 2-8.

[41] Trilling, B. and Fadel, C. (2009), 21st Century Skills: Learning for Life in our Times, JosseyBass, San Franciso.

[42] Trivedi, A. (2013) A Study of Literature Review on Individual Accountability, doi: https://dx.doi.org/10.2139/ssrn.2314551.

[43] Unni, J. (2016) Skill Gaps and Employability: Higher Education in India, Journal of Development Policy and Practice, 1 (1), 1-17. doi: $10.1177 / 0000000315612310$ 